\title{
Data collection on maize growth during a field visit in Shan State, Myanmar
}

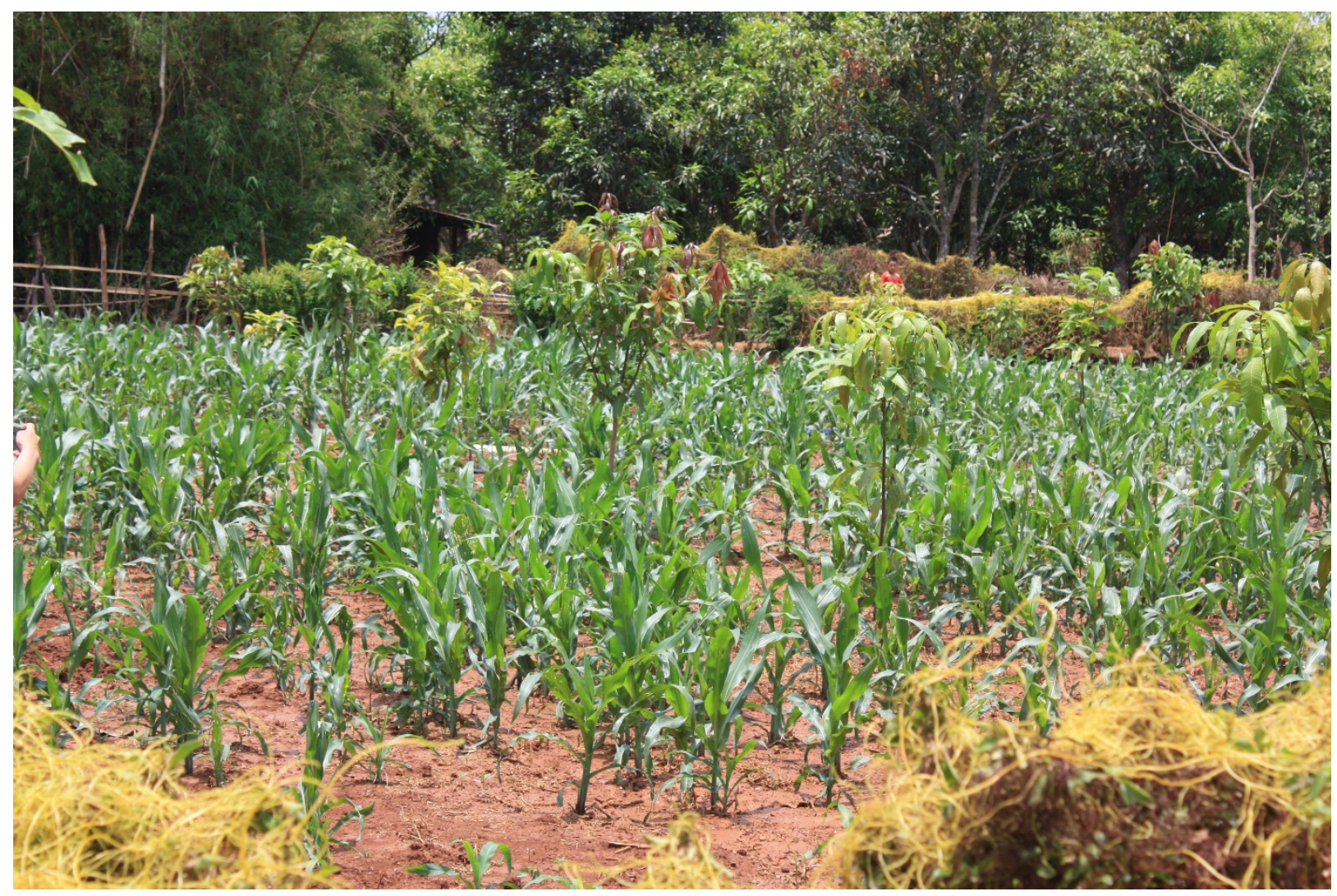

Greet Blom-Zandstra ${ }^{1}$, Yu Tinzar Htet ${ }^{2}$ and Jennifer Lee ${ }^{2}$

${ }^{1}$ Wageningen University \& Research

2 Impact Terra 
Blom-Zandstra, M., Y.Y. Tinzar Htet, J. Lee, 2020. Data collection on maize growth during a field visit in Shan State, Myanmar Wageningen Research, Confidential Report WPR-959. pp.; 28

\section{Summary}

Although maize yields in Myanmar has been more than doubled since the year 2000, productivity of maize growth is still low. In The SAM project 'Geodata for Agriculture and Water Facility', maize growers, organized in the Golden Paddy Platform, are supported to improve their farm management practices in order to optimize their yields and close the yield gap. Therefore, an in-app advice-rating system is developed for facilitating the farmers. During a field visit farmers were interviewed to collect baseline data to enable the monitoring of the effectiveness and impact of the tool. The visits and data collection showed that farmers are aware of the importance of proper land preparation and fertilization and all farmers are motivated to improve their farm management practice, but no farmer logged its data. It was noticed, that yields varied considerably between farmers. Some yields were below the national average. It appeared, that most farmers did not provide the amount of fertilizer according to the recommendations of the Golden Paddy GAP booklet. Some farmers had identified the Fall army worm. It is recommended to ask farmers lo log their farm management practices for empowering them by concrete figures and positive trends.

This report can be downloaded for free at https://doi.org/10.18174/516092

(C) 2019 Wageningen, Stichting Wageningen Research, Wageningen Plant Research, Business Unit Agrosystems, P.O. Box 16, 6700 AA Wageningen, The Netherlands; T +31 (0)317 4807 00; www.wur.eu/plant-research

Chamber of Commerce no. 09098104 at Arnhem

VAT NL no. 8065.11.618.B01

Stichting Wageningen Research. All rights reserved. No part of this publication may be reproduced, stored in an automated database, or transmitted, in any form or by any means, whether electronically, mechanically, through photocopying, recording or otherwise, without the prior written consent of the Stichting Wageningen Research.

Stichting Wageningen Research is not liable for any adverse consequences resulting from the use of data from this publication.

\section{Report WPR-959}

Photo cover: Maize field in Shan State, Myanmar (M. Blom-Zandstra) 


\section{Contents}

1.1 Introduction

1.2 Field trip

2.1 Field visit farmers

2.2 Soil test kits

\section{Results}

3.1 Visits of the farms

3.1.1 Main characteristics farm management 9

3.1.2 Land preparation 9

$\begin{array}{ll}3.1 .3 \text { Planting (cultivars, spacing) } & 10\end{array}$

$\begin{array}{ll}3.1 .4 \text { Weeding } & 10\end{array}$

$\begin{array}{ll}3.1 .5 \text { Soil tests } & 10\end{array}$

3.1.6 Fertilizer use $\quad 10$

3.1.7 Scouting pest and diseases, with special attention to Fall Army Worm 10

3.1.8 Harvesting (yields 2018) 11

3.1.9 Recommendations made to the farmers 11

3.2 Relationships $\quad 12$

3.2.1 Yield - land preparation 12

$\begin{array}{ll}3.2 .2 \text { Yield - cultivar } & 12\end{array}$

$\begin{array}{ll}3.2 .3 \text { Yield - fertilizer } & 13\end{array}$

4

$\begin{array}{ll}\text { Discussion } & 15\end{array}$

$\begin{array}{lll}4.1 & \text { Farm management practice } & 15\end{array}$

$\begin{array}{lll}4.2 & \text { Fall armyworm } & 16\end{array}$

$\begin{array}{lll}4.3 & \text { Recommendations } & 16\end{array}$ 


\section{Collection of baseline data for the Golden Paddy App}

\subsection{Introduction}

Myanmar is a maize producing and exporting country among 163 maize producing countries ${ }^{1}$ in the world. In this country, maize is the second mandate cereal after rice. Maize crop are produced regularly in Northern Shan State, Mandalay Region and Ayeyawaddy Region.

Productivity of the maize growth in Myanmar (3.8 tonnes/ha in 2018, according to FAOSTAT; 4.2 tonnes/ha according to USDA-Fas) is low in comparison to the neighbouring maize producing country Bangladesh, but it shows similar productivity with India and Thailand (Figure 1A). Yet, maize productivity has been more than doubled since 2000 (Figure 1B) indicating its potency for improvement. In The SAM project 'Geodata for Agriculture and Water Facility', maize growers are supported to improve their farm management practices in order to optimize their yields and close the yield gap.

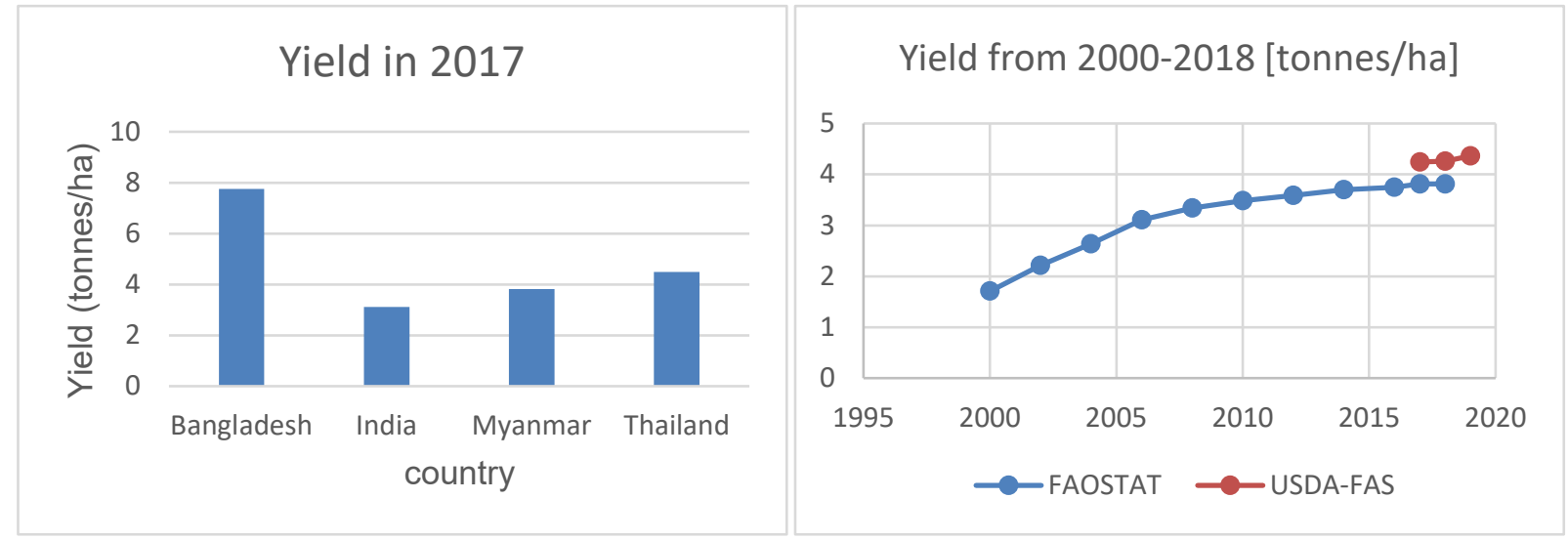

Figure 1. A. The yields (tonnes/ha) of maize in 2017 in Bangladesh, India, Myanmar and Thailand (Source: FAOSTAT); B. The yields in Myanmar from 2000 until 2018 (sources: FAOSTAT and USDA-FAS)

In this innovative SAM project, an in-app advice-rating system is developed in order to support and facilitate farmers, organized in the Golden Paddy platform, in making appropriate decisions on their farm management practice (e.g. on fertilization dose and timing, etc.). So, maize growers in Shan State are provided by knowledge and build up expertise to enhance their farm management practice towards Good Agricultural Practices and accredited certification (GAP-certification).

For an adequate development of this in-app advice-rating system, baseline data has to be collected as a starting point and to be able to monitor the effectiveness and impact of the tool. Therefore, farmers are interviewed on their common field management practices, use of fertilizers and chemicals, and their yields.

\footnotetext{
${ }^{1}$ http://www.mpbsma.org/products/maize
} 


\section{$1.2 \quad$ Field trip}

From May $13^{\text {th }}$ until May $16^{\text {th }}$ a field trip was organised in Shan State in which we visited 8 farmers growing maize within the region depicted by the yellow circle in the map (Figure 2). The concrete aim of the visit was to observe the farmers' practices, to advise simple affordable soil testing kit and conducting soil samples, to come up with recommendations for improvement maize yields and to train the agronomy staff how to assist farmers and planning an fertilization program. During the field visits we focussed on:

- Farm visits to observe current practices and interviews with select farmers (focusing on practices important to combatting FAW such as spacing, intercropping, etc.)

- $\quad$ Soil sampling and showing IT staff easy method to sample

- Retailer visits to see common products available (if time permits)

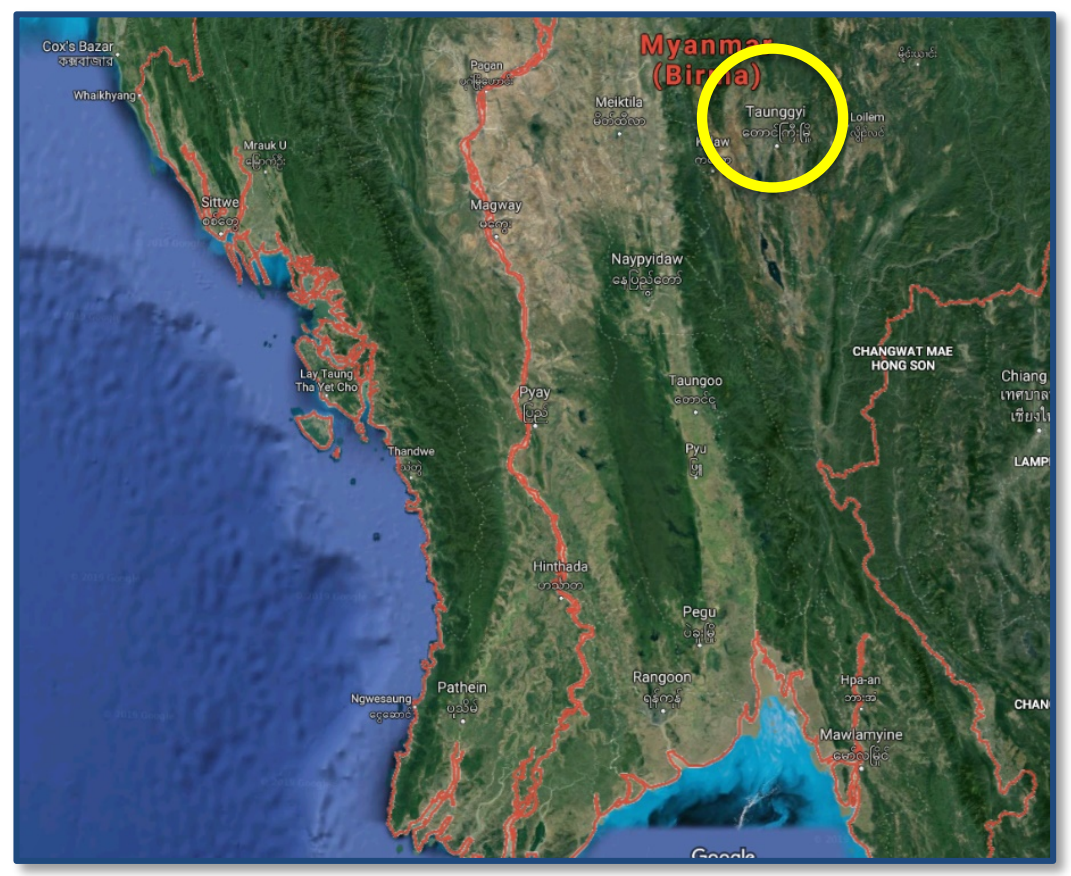

Figure 2. Region in Shan State in which farmers were selected for the visit (Map: Google maps) 


\section{Methods}

\section{$2.1 \quad$ Field visit farmers}

In total 8 farmers were selected for the interviews. All farmers belonged to the Golden Paddy Platform and were connected to the Golden Paddy App. The farmers we visited and their location are summarized in Table 1.

Table 1. Farmers selected for the visit and their residence.

\begin{tabular}{|c|l|l|}
\hline Farmer & Name & Location \\
\hline 1 & Ko Sai Khan Htee & Than Te village within Than Te Village Tract \\
2 & Ko Khan Lone & Than Te village within Than Te Village Tract \\
3 & Ko Aung Thu & Hle Toe Village, Pin Pyit Village Tract, Yatsaunk Township \\
4 & Ko Mya Lwin Oo & Inn Mee Village, Hway Village Tract, Yatsaunk Township \\
5 & Ma San San Yee & Sin Thay Village, Myin Taung Village Tract in Yatsaunk Township \\
6 & Ko Khun Than Lay & Kyauk ka Char Village, Sam Hpu Village Tract in Ho Pone Township \\
7 & Ko Naing Win Htun & Yatsaunk Village, Yatsaunk Township \\
8 & Ko Kyaw Win Zaw & Ah Lel Chaung Village, Yatsaunk Township \\
\hline
\end{tabular}

Farmers were interviewed by a semistructured interview method and asked about:

- Land preparation

- $\quad$ Planting (spacing, cultivars)

- Weeding

- Fertilizer use

- $\quad$ Scouting pest and diseases, with special attention to Fall Army Worm

- Harvesting (yields 2018)

If possible, the fields were visited (Figure 3) to see the status of the soil. Samples were taken roughly in the middle of the field by digging a whole of about $10-15 \mathrm{~cm}$ depth. At that depth a soil sample (the amount of a handful) was taken for soil analyses on N, P,

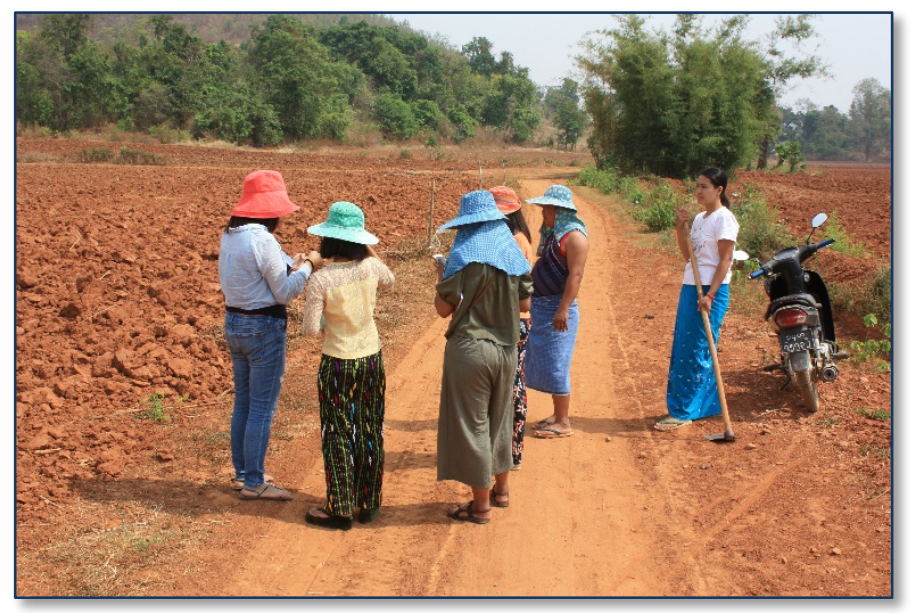

Figure 3. Visit of the plot intended for maize production $\mathrm{K}$ and $\mathrm{pH}$. Soil samples were analysed at the farm while the course of action was shown to the farmer(s) using a simple soil test kit. For explanation: see below.

\subsection{Soil test kits}

Soil acidity or alkalinity influences how easily plants take up nutrients from the soil. The standard $\mathrm{pH}$ for soils usually ranges between 4.0 and 8.5. Most garden plants favour soil which has a pH between 6.5 and 7 because this is the level where nutrients and minerals naturally thrive.

For farming according to GAP it is very important to know soil $\mathrm{pH}$ and the availability of $\mathrm{N}, \mathrm{P}$ and $\mathrm{K}$ in the soil. Based on these data, recommendations can be given on the addition of lime and fertilizers. 
For analysis of $\mathrm{pH}, \mathrm{N}, \mathrm{P}$ and $\mathrm{K}$, a simple Garland soil test kit (Figure 4) was purchased online ${ }^{2}$ and is available from several resellers including Amazon.

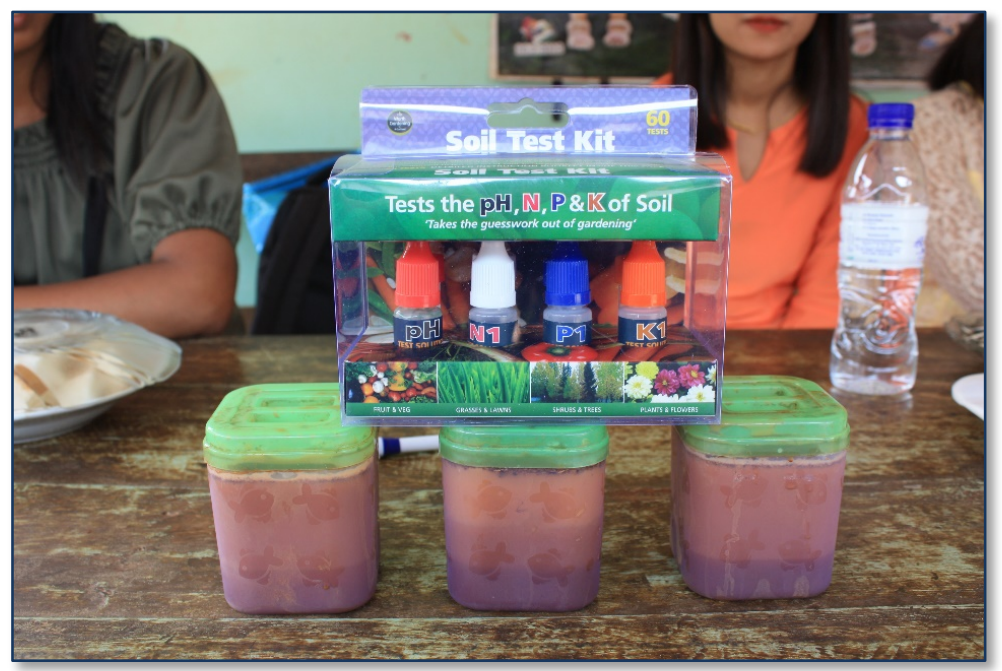

Figure 4. Garland Soil test kit

The soil test kit provides qualitative information on soil status and is easy to use. Simply, mix a soil sample with water in a jelly jar and shake for about 1 minute. Let the solution settle for a few minutes. Then, transfer with the pipette the indicated quantity of the solution into the test tube (Figure 5, included in the test kit). Add a pinch of the powder from the matching colour capsule (included in the test kit), and wait while the accompanying colour of the solution develops. After 5 minutes, the colour of soil solution has to be compared to the colour reading charts described in the guidelines (Figure 6 , included in the test kit). For $\mathrm{N}-\mathrm{P}-\mathrm{K}$ test results, the nutrient levels are indicated on a scale from 0 (depleted) to 4 (surplus); $\mathrm{pH}$ test results are indicated on a scale from 4.5 to 7.5.

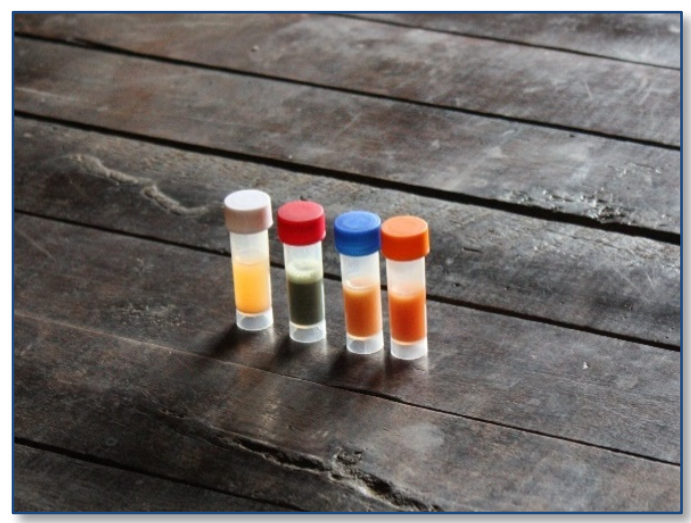

Figure 5. Tubes for soil analyses

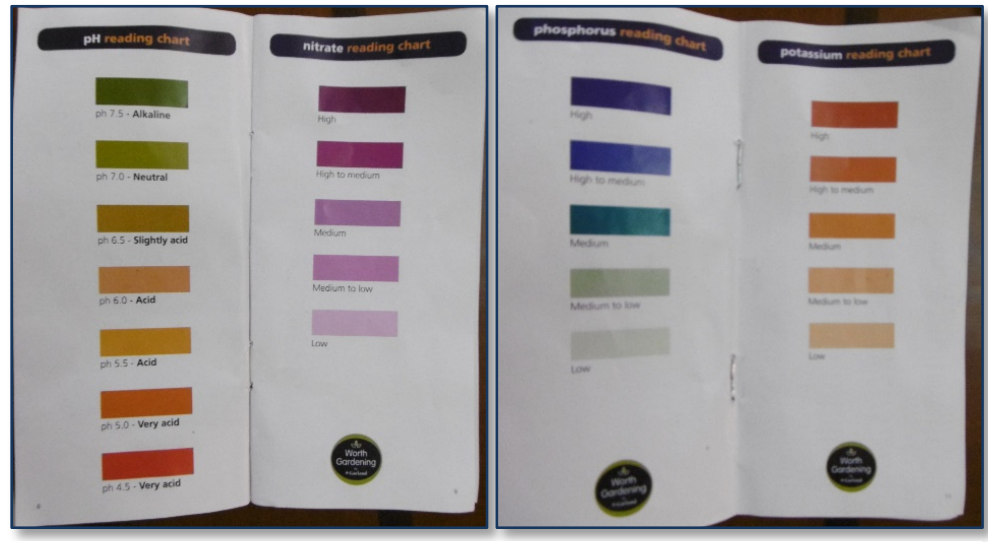

Figure 6. Colour reading chart for quick analyses of respectively $\mathrm{pH}$, nitrate, phosphorus and potassium (from left to right)

\footnotetext{
${ }^{2}$ https://www.tuincentrumlopik.com/bodem-npk-ph-test-kit-60tests.html?gclid=CjwKCAiA98TXBRBtEiwAVRLquyaOgnUfhIvWj7udjyglhXL96HCBp2SNgf8V4OzkvmiSpCGKMaRDDBoCjTkQ AvD BwE
} 


\section{Results}

\subsection{Visits of the farms}

The time needed to visit the 8 farmers could be scheduled in 3 days. In the interviews the farmers provided information on plot sizes, their farm management practice and yield. Most farmers had done their land preparation already, but no farmer had yet applied fertilizer. The minutes of the interviews are displayed in Annex 1.

\subsubsection{Main characteristics farm management}

The farm sizes mentioned by the farmers in acres are summarized in Table 2 and converted to hectares for comparison with the international standards. Farm sizes varied considerably. Generally, the farmers had several plots, differing in size. For some farmers the plots were a long way apart, requiring much travelling time (several hours) for the farmer to reach it.

Table 2. Farm sizes and the amount of plots of the visited farmers.

\begin{tabular}{|c|cc|c|}
\hline Farmer & \multicolumn{2}{|c|}{ Farm size } & Number of plots \\
\hline & acres & ha & \\
\hline 1 & 8 & 3.2 & 3 \\
\hline 2 & 12 & 4.9 & 4 \\
\hline 3 & 27 & 10.9 & 4 \\
\hline 4 & 14 & 5.7 & 2 \\
\hline 5 & 30 & 12.1 & 4 \\
\hline 6 & 5 & 2.0 & 2 \\
\hline 7 & 5 & 2.0 & 1 \\
\hline 8 & 8 & 3.2 & 1 \\
\hline
\end{tabular}

Four farmers mentioned that they had grown other crops as precursor for maize and used the residues as green manure. Following precursor crops were mentioned: beans, potato, garlic, chickpea and pigeon pea. Two farmers also grew Mango. Some farmers based their farm management on advice from family, neighbours or friends. Others followed the advice of extension officers.

\subsubsection{Land preparation}

Most farmers prepared the soil by ploughing manually with a spade, some of them several times, while only three farmers used machinery (rented or in own possession) for soil preparation (Figure 7). All farmers applied fertilizer before planting, but the amounts differed between farmers.
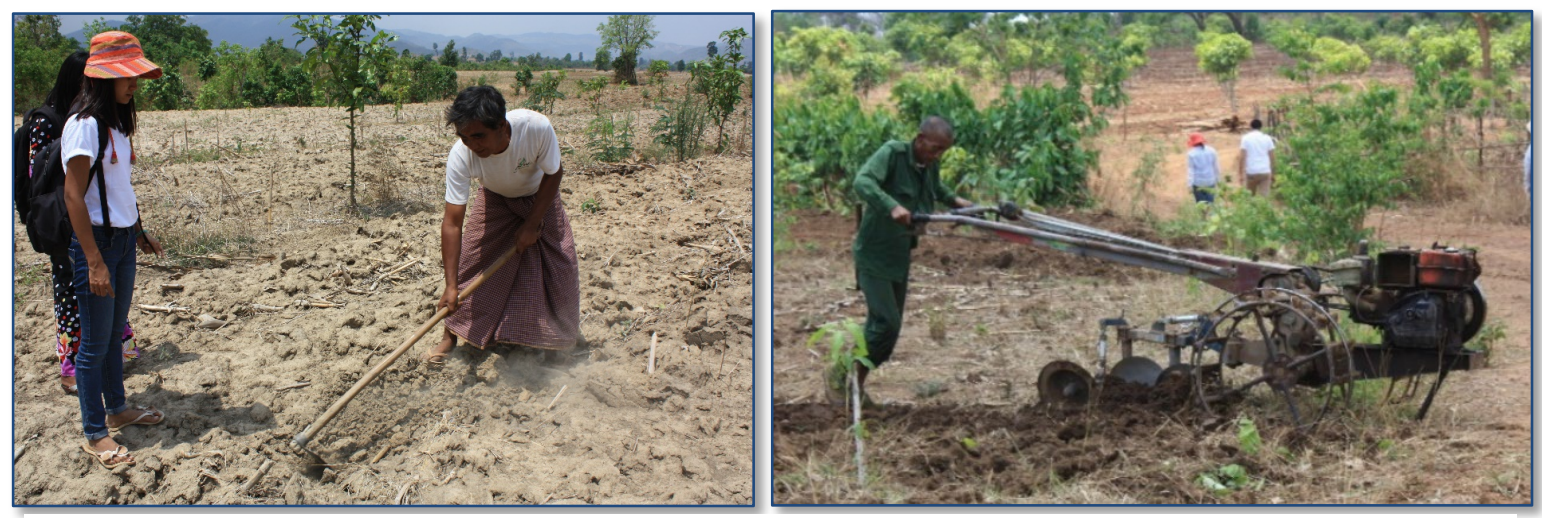

Figure 7. Farmers ploughing manually (left) or with tiller machine (right) 


\subsubsection{Planting (cultivars, spacing)}

The farmers used different cultivars. The cultivar CP 808 was selected most ( 4 farmers). Other cultivars used were: CP 888, CP 282, AK 111, GT 722, NK 625 NK 621, 139 or Thai 555. The motivations for the selection differed between farmers and can be seen in Annex 1 .

Plant spacings were rather similar between farmers and rather well corresponded to the recommendations in the Golden Paddy GAP booklet (Row: 2.4 feet ( $=28,8$ inches or $73,18 \mathrm{~cm}$ ); Plant distance: 0.5 feet (= 6 inches or $15,24 \mathrm{~cm}$ ).

\subsubsection{Weeding}

Generally, the weeding was done two times, a few days after planting and just before fertilization. Half of the interviewed famers did the weeding manually, while 3 farmers used herbicides.

\subsubsection{Soil tests}

The fertility of the soil was tested at 6 farms. The results from the soil tests are shown in Table 3.

Table 3. Results from soil analyses op pH, nitrogen, phosphorus and potassium determined by colour chart.

\begin{tabular}{|c|c|c|c|c|c|}
\hline Farmer & Plot & $\mathbf{p H}$ & $\mathbf{N}$ & $\mathbf{P}$ & $\mathbf{K}$ \\
\hline 1 & 1 & $>7.5$ & low & medium & medium \\
\hline & 2 & $>7.5$ & low & medium & medium \\
\hline 2 & 1 & $>7.5$ & medium to low & medium to low & medium to low \\
\hline & 2 & $>7.5$ & medium to low & medium to low & medium to low \\
\hline & 3 & $>7.5$ & very low & medium & medium \\
\hline & 4 & $>7.5$ & low & medium to low & medium to low \\
\hline 3 & 1 & $>7.5$ & very low & medium & medium-low \\
\hline & 2 & $>7.5$ & very low & low-medium & medium \\
\hline 4 & 1 & $>7.5$ & low & medium-low & low \\
\hline 5 & 1 & $>7.5$ & low & low & low \\
\hline & 2 & $>7.5$ & low & low & low \\
\hline 6 & 1 & $>7.5$ & medium & - & medium \\
\hline
\end{tabular}

In all samples, $\mathrm{pH}$ was high and the availability of the nutrients NPK was medium or low. The values of $\mathrm{pH}$ correspond with the relatively high values for the Shan State region, depicted at Soilgrids ${ }^{3}$. At high $\mathrm{pH}$ the iron metal ( $\mathrm{Fe}$ ) will be released from the soil-particle-complexes and damage by $\mathrm{Fe}$ toxicity may occur. However, no such damage was seen on the plants in the neighbouring field where maize was already growing.

\subsubsection{Fertilizer use}

Almost all farmers applied fertilizer (both NPK and urea) two times: at planting and around 45 days after planting. Generally, they used 1 bag/acre, except for 1 farmer who started with 4 bags/acre. Two farmers used cow manure before planting. For further details: see annex 1.

\subsubsection{Scouting pest and diseases, with special attention to Fall Army Worm}

In many leaves the effects of glutton were seen (Figure 8). The frequency of scouting of pests and especially the detection of Fall Army Worm are shown in Table 4. Clearly, 5 farmers were aware of the possible outbreak of pests and diseases and payed attention to it. Three farmers mentioned to have detected the Fall Armyworm, but they had not yet taken measurements to combat them.

\footnotetext{
3 https://soilgrids.org/\#!/?lon=96.8269218\&lat=20.7187712\&zoom=14\&layer=ORCDRC_M_sl3_250m\&vector=1\&showInfo=1
} 
Table 4. Frequency of scouting, detection and control measure performed by the visited farmers.

\begin{tabular}{|c|c|c|c|}
\hline Farmer & Scouting for pests & Detection FAW & Control \\
\hline 1 & Two times a week & + & - \\
\hline 2 & Two times a week & + & - \\
\hline 3 & No & - & - \\
\hline 4 & No & - & - \\
\hline 5 & No & - & - \\
\hline 6 & One time a week & + & - \\
\hline 7 & Everyday & - & - \\
\hline 8 & One time a week & - & - \\
\hline
\end{tabular}

\subsubsection{Harvesting (yields 2018)}

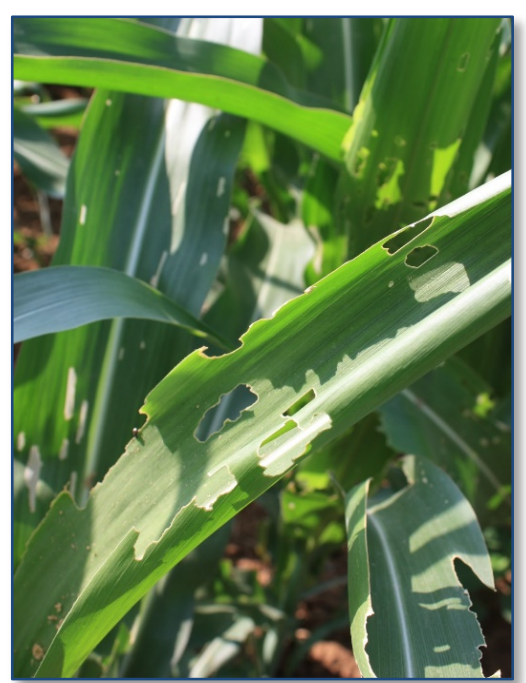

Figure 8. Maize affected by glutton

The yields over 2018 that were mentioned ${ }^{4}$ by the farmers are shown in Table 5 . As can be seen, the yields varied considerably between the farmers and also between plots at the same farmer. At $50 \%$, the yields were lower than the national average (3.8 tonnes/ha ${ }^{5}$, see chapter 1 ).

Table 5. Mentioned maize yields at the farms/plots in 2018.

\begin{tabular}{|c|c|c|c|}
\hline \multirow{2}{*}{ Farmer } & \multirow{2}{*}{ Plot } & \multicolumn{2}{|c|}{ Yield } \\
\cline { 3 - 4 } & & Viss/acre) & Tonnes/ha \\
\hline 1 & $1-3$ & 1650 & 6.66 \\
\hline 2 & $1-4$ & 1300 & 5.25 \\
\hline 3 & 1 & 960 & 3.87 \\
\hline & $2-4$ & 1478 & 5.96 \\
\hline 4 & 1 & 587 & 2.37 \\
\hline & 2 & 1205 & 4.86 \\
\hline 5 & 1 & 714.3 & 2.88 \\
\hline & 2 & 700 & 2.82 \\
\hline & 3 & 533 & 2.15 \\
\hline & 4 & 880 & 3.55 \\
\hline 6 & 1 & 1250 & 5.04 \\
\hline & 2 & 0 & 0.00 \\
\hline 7 & 1 & 800 & 3.23 \\
\hline 8 & 1 & 1500 & 6.05 \\
\hline & & & \\
\hline
\end{tabular}

\subsubsection{Recommendations made to the farmers}

Based on the recommendations, described in the Golden Paddy GAP booklet, we noted that almost all farmers applied a suboptimal quantity of fertilizer. However, the farmers indicated that the recommended fertilizer applications from the Golden Paddy GAP booklet were too expensive and too risky because of a possible outbreak of Fall Armyworm. So, our recommendations during this visit (see Annex 1) did not fully meet the necessary crop demand, but were connected to the farmers' normal habit., A switch to the required fertilizer application rate is currently too risky for farmers.

\footnotetext{
${ }^{4}$ Yield data were based on the farmers' memory, as they were not logged

5 Source: FAOSTAT
} 


\subsection{Relationships}

To study the variation in crop yields in more detail, we zoom in on the relationship between 1 . Yield and land preparation, 2. Yield and cultivar and 3. Yield and fertilizer application. Unfortunately, due the low number of data and the lack of replicates, we are not able to perform statistical analysis and only weak trends might be seen.

\subsubsection{Yield - land preparation}

Table 6. Yields (in 2018) at different farms/plots and farm management on these plots.

\begin{tabular}{|c|c|c|c|c|}
\hline Farmer & $\begin{array}{c}\text { Yield } \\
\text { (viss/acre) }\end{array}$ & Plot & Land preparation & Extra \\
\hline 1 & 1650 & $1-3$ & $\begin{array}{l}\text { ploughed, and again after } \\
\text { rain }\end{array}$ & $\begin{array}{l}\text { possibility for irrigation, extra } \mathrm{N}- \\
\text { application, no pesticides HOWEVER } \\
\text { ACETOMIPRID (insecticide) }\end{array}$ \\
\hline 2 & 1300 & $1-4$ & $\begin{array}{l}\text { tractor (harrowing and } \\
\text { planting) }\end{array}$ & $\begin{array}{l}\text { no irrigation, use of herbicides and } \\
\text { insecticides preventive and higher dose if } \\
\text { disease present }\end{array}$ \\
\hline \multirow[t]{2}{*}{3} & 960 & 1 & \multirow[t]{2}{*}{ big tractor } & \multirow[t]{2}{*}{ Use of herbicides, no insecticides } \\
\hline & 1478 & $2-4$ & & \\
\hline \multirow[t]{2}{*}{4} & 587 & 1 & \multirow[t]{2}{*}{ ploughed } & \multirow[t]{2}{*}{ uses false weed beds, no herbicides } \\
\hline & 1205 & 2 & & \\
\hline \multirow[t]{4}{*}{5} & 714.3 & 1 & $?$ & \\
\hline & 700 & 2 & $?$ & \\
\hline & 533 & 3 & $?$ & \\
\hline & 880 & 4 & $?$ & \\
\hline 6 & 1250 & 1 & harrowing & \\
\hline 7 & 800 & 2 & harrowing & no fertilizer at planting \\
\hline 8 & 1500 & 1 & $?$ & \\
\hline
\end{tabular}

From table 6, it can be concluded that the use of machinery does not appear to result in higher yields than harrowing manually. Use of biocides appears to have an effect.

\subsubsection{Yield - cultivar}

Table 7. shows the choice for different cultivars in 2018 and their yields. Some farmers selected different cultivars for different plots (Figure or even combinations of cultivars (farmer 5). It can be seen that Cultivar CP 808 (marked green) appears to achieve the best, followed by AK 111 .

Table 7. Yields (2018) at different farms/plots and the different maize cultivars, grown on these plots.

\begin{tabular}{|c|c|c|l|}
\hline Farmer & Plot & $\begin{array}{c}\text { Yield } \\
\text { (viss/acre) }\end{array}$ & Cultivars \\
\hline 1 & 1 & 1650 & CP 808 \\
\hline & 2 & & CP 808 \\
\hline & 3 & & 139 \\
\hline 2 & 1 & 1300 & AK 111 \\
\hline & 2 & & AK 111 \\
\hline & 3 & & GT 722 \\
\hline & 4 & & CP 888 \\
\hline 3 & 1 & 960 & NK 625 \\
\hline
\end{tabular}




\begin{tabular}{|c|c|c|l|}
\hline & 2 & 1478 & CP 808 \\
\hline & 3 & & CP 808 \\
\hline & 4 & & CP 808 \\
\hline 4 & 1 & 587 & Thai 555 \\
\hline & 2 & 1205 & CP 808 \\
\hline 5 & 1 & 714.3 & $\begin{array}{l}\text { NK 625, NK } \\
621, \text { CP 808 } \\
\text { and 282 }\end{array}$ \\
\hline & 2 & 700 & $\begin{array}{l}\text { NK 625, NK } \\
621, \text { CP 808 } \\
\text { and 282 }\end{array}$ \\
\hline & 3 & 533 & $\begin{array}{l}\text { NK 625, NK } \\
621, \text { CP 808 } \\
\text { and 282 }\end{array}$ \\
\hline 6 & 1 & 1250 & $\begin{array}{l}\text { NK 625, NK } \\
621, \text { CP 808 } \\
\text { and 282 }\end{array}$ \\
\hline & 2 & & CP 808 808 \\
\hline 7 & 1 & 800 & 288, CP 808 \\
\hline 8 & 1 & 1500 & $?$ \\
\hline
\end{tabular}

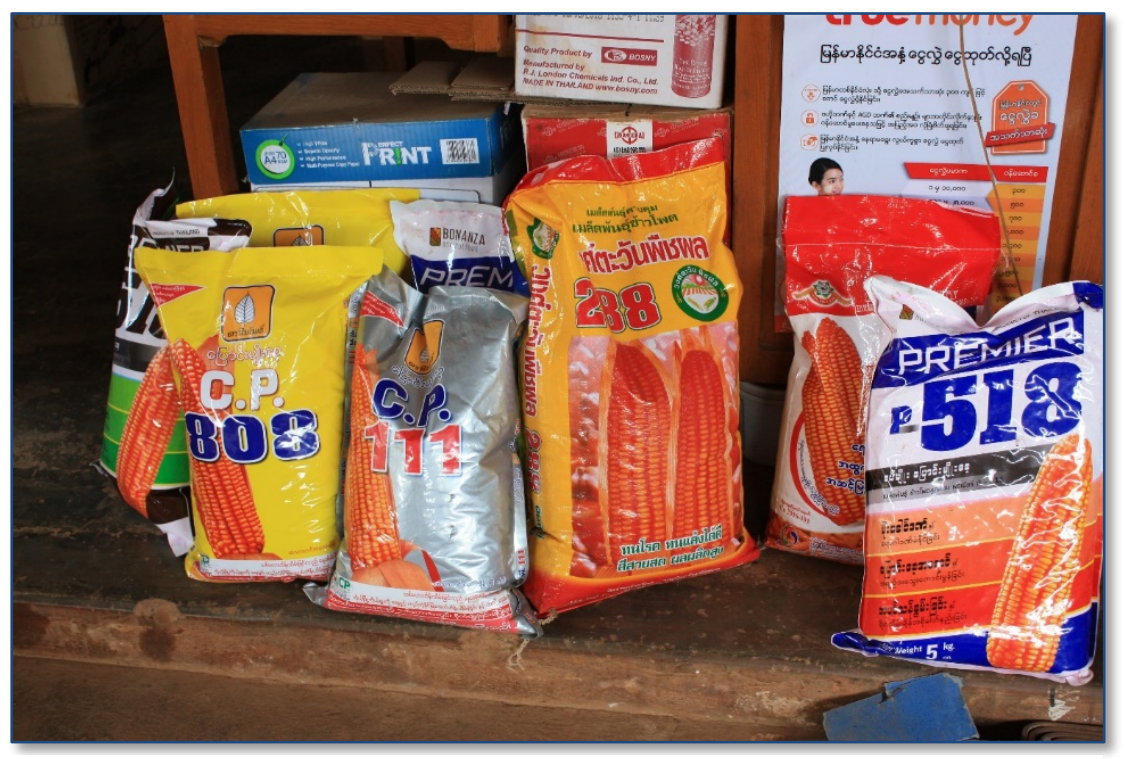

Figure 9. Seeds of different maize cultivars

\subsubsection{Yield - fertilizer}

In Table 8 the yields are compared with the fertilizer application, both the amount and the strategy. Farmer 1, who provided most fertilizer at his first plot, had the highest yield. Unfortunately, no yields are further specified per plot. So, the differences in application between the plots stay unrevealed. In any case, it is difficult to conclude from the table whether the amounts of the fertilizer has effected the yields positively: The differences between farmer 1 , farmer 3 (plot 2) and farmer 8 are small. The application of manure also showed no clear effect on yields, nor did the NPK ratio. Unfortunately, a statistical analysis cannot be done as more data and replicates are necessary for such analysis. 
Table 8. Yields (2018) at different farms/plots and the application of fertilizer on these plots

\begin{tabular}{|c|c|c|c|c|c|c|}
\hline \multirow[t]{2}{*}{ Farmer } & \multirow{2}{*}{\begin{tabular}{|c|} 
Yield \\
(viss/acre) \\
\end{tabular}} & \multirow[t]{2}{*}{ Plot } & \multirow[t]{2}{*}{ Manure } & \multirow{2}{*}{$\begin{array}{l}\text { NPK } \\
\text { ratio }\end{array}$} & \multicolumn{2}{|c|}{ Apllication } \\
\hline & & & & & NPK & Urea \\
\hline \multirow[t]{3}{*}{1} & 1650 & 1 & green remains & $16: 8: 8$ & $\begin{array}{c}4 \text { bags/acre at } \\
\text { planting }\end{array}$ & $\begin{array}{c}1 \text { bag urea/acre after } \\
45 \text { days }\end{array}$ \\
\hline & & 2 & $\begin{array}{c}\text { cow dung }+ \\
\text { green remains }\end{array}$ & & $\begin{array}{c}1 \text { bag/acre }{ }^{6} \text { at } \\
\text { planting }\end{array}$ & $\begin{array}{c}1 \text { bag/acre after } 45 \\
\text { days }\end{array}$ \\
\hline & & 3 & & & 1 bag/acre at planting & $\begin{array}{c}1 \text { bag/acre after } 45 \\
\text { days }\end{array}$ \\
\hline \multirow[t]{4}{*}{2} & 1300 & 1 & & & $1 \mathrm{bag} /$ acre at planting & $\begin{array}{c}1 \text { bag/acre after } 45 \\
\text { days }\end{array}$ \\
\hline & & 2 & & & 1 bag/acre at planting & $\begin{array}{c}1 \text { bag/acre after } 45 \\
\text { days }\end{array}$ \\
\hline & & 3 & & & $1 \mathrm{bag} /$ acre at planting & $\begin{array}{c}1 \text { bag/acre after } 45 \\
\text { days }\end{array}$ \\
\hline & & 4 & & & 1 bag/acre at planting & $\begin{array}{c}1 \text { bag/acre after } 45 \\
\text { days }\end{array}$ \\
\hline \multirow[t]{4}{*}{3} & 960 & 1 & & $15: 7: 8$ & $1 \mathrm{bag} / \mathrm{acre}$ at planting & $\begin{array}{l}1 \text { bag/acre at } \\
\text { tasselling }\end{array}$ \\
\hline & 1478 & 2 & & $15: 7: 8$ & $1 \mathrm{bag} / \mathrm{acre}$ at planting & $\begin{array}{c}1 \text { bag/acre at } \\
\text { tasselling }\end{array}$ \\
\hline & & 3 & & $15: 7: 8$ & 1 bag/acre at planting & $\begin{array}{c}1 \text { bag/acre at } \\
\text { tasselling }\end{array}$ \\
\hline & & 4 & & $15: 7: 8$ & 1 bag/acre at planting & $\begin{array}{c}1 \text { bag/acre at } \\
\text { tasselling }\end{array}$ \\
\hline \multirow[t]{2}{*}{4} & 587 & 1 & & $15: 15: 15$ & $\begin{array}{c}1 \text { bag Armo/acre at } \\
\text { planting }\end{array}$ & - \\
\hline & 1205 & 2 & & $15: 15: 15$ & $\begin{array}{c}1 \text { bag Armo/acre at } \\
\text { planting }\end{array}$ & - \\
\hline \multirow[t]{4}{*}{5} & 714.3 & 1 & & $20: 10: 5$ & $1 \mathrm{bag} / \mathrm{acre}$ at planting & $\begin{array}{c}1 \text { bag/acre at } \\
\text { tasselling }\end{array}$ \\
\hline & 700 & 2 & & $20: 10: 5$ & 1 bag/acre at planting & $\begin{array}{c}1 \text { bag/acre at } \\
\text { tasselling }\end{array}$ \\
\hline & 533 & 3 & & $20: 10: 5$ & 1 bag/acre at planting & $\begin{array}{c}1 \text { bag/acre at } \\
\text { tasselling }\end{array}$ \\
\hline & 880 & 4 & & $20: 10: 5$ & 1 bag/acre at planting & $\begin{array}{c}1 \text { bag/acre at } \\
\text { tasselling }\end{array}$ \\
\hline \multirow[t]{2}{*}{6} & 1250 & 1 & & $20: 10: 5$ & 1 bag/acre at planting & $\begin{array}{c}1 \text { bag/acre after } 45 \\
\text { days }\end{array}$ \\
\hline & & 2 & & $20: 10: 5$ & 1 bag/acre at planting & $\begin{array}{c}1 \text { bag/acre after } 45 \\
\text { days }\end{array}$ \\
\hline 7 & 800 & 1 & $\begin{array}{l}\text { cow manure } \\
\text { (on } 4 \text { acres) }\end{array}$ & $20: 10: 5$ & $\begin{array}{c}1 \mathrm{bag} / \mathrm{bag} \text { seed (= } 1.2 \\
\text { bag/acre) at planting }\end{array}$ & $\begin{array}{c}1 \text { bag/acre after } 45 \\
\text { days }\end{array}$ \\
\hline 8 & 1500 & 1 & & & $\begin{array}{c}1 \text { bag ARMO/acre at } \\
\text { planting }\end{array}$ & $\begin{array}{c}1 \text { bag/acre after } 45 \\
\text { days }\end{array}$ \\
\hline
\end{tabular}

\footnotetext{
${ }^{6}$ Farmer applies less in this field as he considers the soil being good.
} 


\section{Discussion}

The visit of farmers (Figure 10) provided a good insight their usual farm management and the underlying motivation. The farmers were willing to give information on their farm management, yields, bottlenecks and income. Moreover, they all were open minded for enhancement of their agricultural practices. Farm management practices varied between the farmers. Some of the interviewees based their decisions on the Golden Paddy GAP booklet as indicated by extension officers, others followed the advice of neighbours, friends or family.

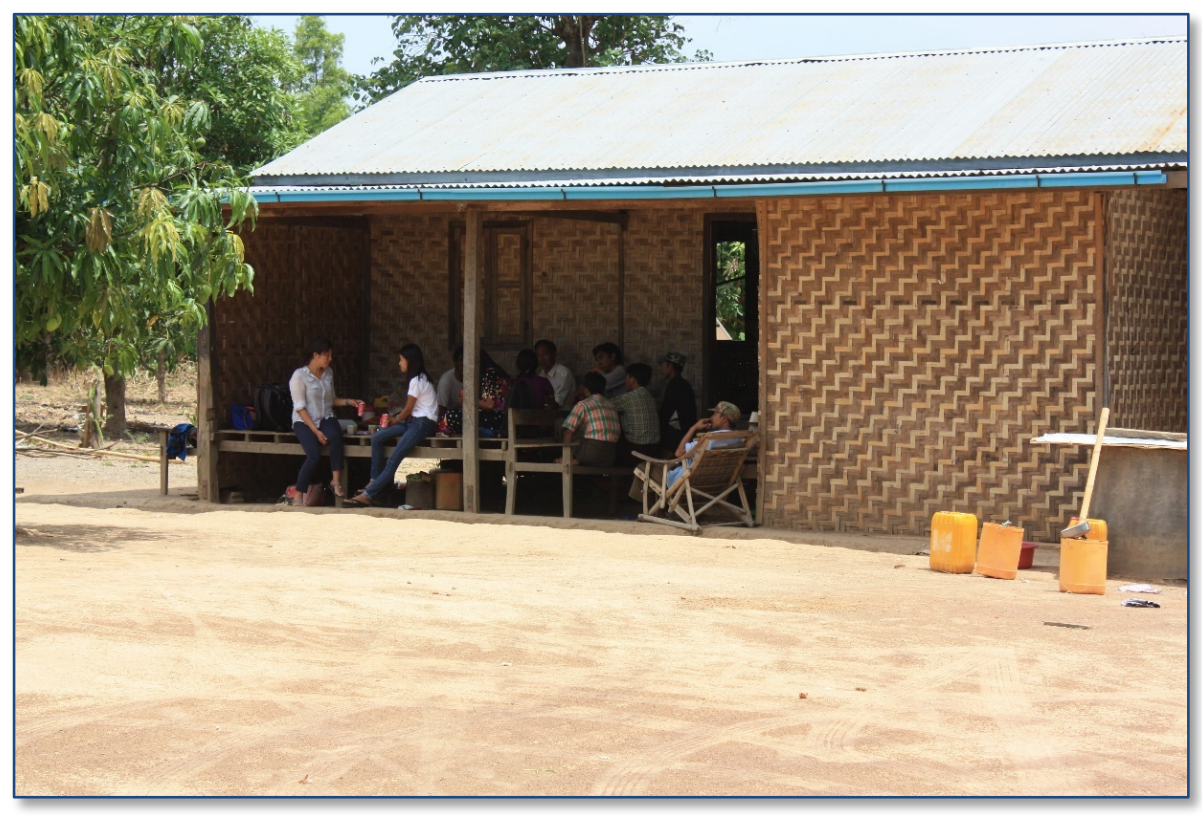

Figure 10. Farm visit

\subsection{Farm management practice}

A clear conclusion can be drawn about the cultivar choice. The cultivar CP 808 achieves bests and is worthwhile to be recommended as preferred cultivar.

The yields varied considerably between farmers. Some yields were below the national average (3.8 tons/ha), others above (up to 6.7 tons/ha). However, it is difficult to draw clear conclusions with respect to the relationships between crop yield and 1. Land preparation and 2.Fertilizer application. All farmers (except for farmer 1, plot 1) applied less fertilizer than recommended for maize and advised in de Golden Paddy GAP booklet (e.g. 4 bags/acre for the whole season), which is needed to meet the crop's demand for optimal growth (see references). In the soil samples the amount of nutrients turned out to be low, confirming that soil nutrient status was poor. So, fertilizer supply had been suboptimal as were the yields. Therefore, we recommended during the visits to increase nutrient supply as much as possible according to the farmer's financial capacity.

Farm management practices on weeding (manually, mechanically or use of biocides) also did not relate clearly with yields and does not perform clear insights in whether the way of farm management recommended by the Golden Paddy GAP booklet turned out to be beneficial.

The monitoring of success in relation to yield at smallholder farms is very difficult as long as the amount of farmers is limited (no sound statistics possible), the plot sizes are small (no added value of mechanical land preparation and weeding, except for time consumption) and all information was qualitative and based on farmers' memory, while no data logging has been done (reliability of data based on memory). 


\subsection{Fall armyworm}

Three farmers mentioned the detection of the Fall armyworm and showed to be aware of the threats of this invasive, epidemic pest. Outbreak of Fall armyworm may be disastrous and may quickly destroy the whole crop. However, detection of the Fall Armyworm and being able to distinguish it from the native and less damaging Asian stem borer and Spotted stalk borer are sometimes difficult and needs knowhow and careful analysis (see references). The poster (Figure 11) shows some characteristics of the three different type of stemborers.

\begin{tabular}{|c|c|c|c|}
\hline & Fall armyworm & $\begin{array}{c}\text { Asian stem } \\
\text { borer }\end{array}$ & $\begin{array}{c}\text { Spotted stalk } \\
\text { borer }\end{array}$ \\
\hline $\begin{array}{c}\text { Scientific } \\
\text { names }\end{array}$ & $\begin{array}{l}\text { (Spodoptera } \\
\text { frugiperda) }\end{array}$ & $\begin{array}{l}\text { (Ostrinia } \\
\text { furnascalis) }\end{array}$ & (Chila partellus) \\
\hline \multicolumn{4}{|l|}{$\begin{array}{l}\text { Appearance } \\
\text { Eggs }\end{array}$} \\
\hline \multicolumn{4}{|l|}{$\begin{array}{c}\text { Appearance } \\
\text { Larvae }\end{array}$} \\
\hline \multicolumn{4}{|l|}{$\begin{array}{l}\text { Appearance } \\
\text { Puppae }\end{array}$} \\
\hline \multicolumn{4}{|l|}{$\begin{array}{l}\text { Appearance } \\
\text { Mots }\end{array}$} \\
\hline $\begin{array}{l}\text { Main food } \\
\text { sources }\end{array}$ & $\begin{array}{l}\text { Maize, rice, sorghum, } \\
\text { sugarcane, vegetable } \\
\text { crops, cotton }\end{array}$ & $\begin{array}{l}\text { Maize, bell pepper, } \\
\text { cotton, millet, } \\
\text { sugarcane, } \\
\text { sorghum, ginger }\end{array}$ & \\
\hline $\begin{array}{l}\text { Natural } \\
\text { enemies }\end{array}$ & Ants, earwigs, bugs & $\begin{array}{c}\text { Tachinid flies, } \\
\text { bracsoic and } \\
\text { ichneumon wasps, } \\
\text { eanvigs }\end{array}$ & wasps \\
\hline Intercropping & $\begin{array}{c}\text { Cassava, dapier grass, } \\
\text { brachiacia grass, beans, } \\
\text { peas }\end{array}$ & $\begin{array}{l}\text { Beans, eggplant } \\
\text { and lemon grass }\end{array}$ & $\begin{array}{l}\text { Sorghum, Cassava, } \\
\text { aapier grass, } \\
\text { desmodium }\end{array}$ \\
\hline Biocontrol & Littoxic, spodoxir. & & $\begin{array}{l}\text { Extra Nitrogen } \\
\text { fertilizer }\end{array}$ \\
\hline
\end{tabular}

Figure 11. Characteristics of Fall armyworm, Asian borer and Spotted stalk borer

\subsection{Recommendations}

The visits and data collection showed that farmers are aware of the importance of proper land preparation and fertilization. All farmers are motivated to improve their farm management practice and are open minded to comply with the recommendations of the Golden Paddy GAP booklet. Some farmers even followed trainings.

The application of fertilizer is a point of attention. Most farmers did not provide the amount of fertilizer according to the recommendations of the Golden Paddy GAP booklet and an increase of the fertilizer application may increase their yield substantially. 
Also the farmer's attention to crop development and the scouting for pests and diseases are important issues to be taken into account. Some farmers pay attention to their maize crop regularly (or weekly), others do no visit the plot at all.

For proper control of crop development, farmers should be asked to log the amounts and applications of fertilizer/pesticides/herbicides, working hours and yields. So, crop development, costs and revenues can be visualized and trends can be identified. Generally, farmers can be empowered by concrete figures and motivated for improvement or innovation. As a method, it can be recommended to select a big group farmers from the Golden Paddy Platform and organize them in different groups ( $>10$ farmers per group) based on comparable soil types and environment (hills or flat land). Ask the farmers to follow crop growth on basis of a protocol, periodical measurements on growth and scouting for the coming up of diseases and concrete weighing of the yields and to log their farm management operations in a simple table:

- Dates of sowing, weeding, application of fertilizer, scouting application of biocides, harvest

- Use of equipment

- Selected cultivars

- Types of fertilizer and pesticides, amounts of application

- Time investment

- $\quad$ Yields and selling prices

Data analyses on these figures give insight in the benefits of controlled farm management and can be used by extension officers to convince the farmer of advantages of the use of enough of fertilizer, to scout for pests and diseases and to save time by mechanization. 


\section{$5 \quad$ References}

Adu, G.B., M.S. Abdulai, H. Alidu, S.K. Nustugah, S. S. Buah, J. M. Kombiok, K. Obeng-Antwi, M. Abudulai, P. M. Etwire, 2015. Recommended Production Practices for Maize In Ghana, https://www.researchgate.net/publication/270511013_Recommended_Production_Practices_for_M aize_in_Ghana 10.13140/2.1.4376.3527

Blom-Zandstra, G., 2018. Good agricultural practices. Manual for proper maize production. Wageningen University \& Research.

FAO, 2018. Integrated management of the Fall Armyworm on maize A guide for Farmer Field Schools in Africa, Food and Agriculture Organization of the United Nations, Rome

Hailu, G., S. Niassy, K. R. Zeyaur, N. Ochatum and Sevgan Subramanian, 2018. Maize-Legume Intercropping and Push-Pull for Management of Fall Armyworm, Stemborers, and Striga in Uganda Agron. J. 110:2513-2522

Hammad, H.M., F. Abbas, A. Ahmad, W. Farhad, C. J. Wilkerson, and G. H. Hoogenboom, 2018. Evaluation of Timing and Rates for Nitrogen Application for Optimizing Maize Growth and Development and Maximizing Yield. Agron. J. 110:565-571

Prasanna, B.M., J. E. Huesing, R. Eddy, V. M. Peschke (eds). 2018. Fall Armyworm in Africa: A Guide for Integrated Pest Management, First Edition. Mexico, CDMX: CIMMYT.

USDA Foreign Agricultural Service, 2016. Corn Production, Supply, and Demand Update 2016. Gain Report Nr BM 6014. Global Agricultural Information Network

Voto, 2017. A complete curriculum and guide to maize production in Ghana. Pp 34. In: http://agricinghana.com/wp-content/uploads/2017/07/maize-production-guide-ghana-2016.pdf 


\section{Annex 1 Interviews}

\section{Day 1: Monday, 13 May}

Farmer 1: Ko Sai Khan Htee (8 acres of maize, a relative of Ma Nwe), used to be the village leader but resigned for health reasons.

Location: Than Te village within Than Te Village Tract.

156 households in the village, all are farmers

120 have their own farms, the rest rent land or are laborers

Most between 35-40 years

Most men do the harrowing and ploughing

Females do planting, weeding, harvesting

$70-80 \%$ of women are farmers

Seed: CP 808 on two plots, Armo 139 on 2 acres

Planting date - waiting for the rain; last week of May/first week of June

Q: How much rain?

A: When the soil is wet enough

Q: What happens if it doesn't rain after you plant?

A: Can irrigate if rain stops

Planting by hand in rows (26-28 inches between) and 6 inches between plants

(NB. GAP recommendation: 2.4 feet between rows and 0.5 feet between plants)

Farmer uses this spacing to be able to weed and for pest management

Farmer has received a lot of training from other companies and NGOs

Farmer has had 20 years of experience, has tested different types of spacing and says if the leaves touch between plants they will turn yellow

Table 9. Field information of farmer 1.

\begin{tabular}{|c|c|c|c|c|c|c|}
\hline Plot & Acres & Seed & Manure & Precursor crops & Soil & Fertilizer \\
\hline 1 & 4 & СР 808 & & $\begin{array}{l}\text { Beans grown, plants used } \\
\text { as green manure }\end{array}$ & $\begin{array}{l}\mathrm{pH}>7.5 \\
\mathrm{~N}: \text { low } \\
\mathrm{P}: \text { medium } \\
\mathrm{K}: \text { medium }\end{array}$ & $\begin{array}{l}4 \text { bags/acre }+1 \text { bag } \\
\text { urea/acre }\end{array}$ \\
\hline 2 & 2 & CP 808 & Cow Dung & $\begin{array}{l}\text { Potato grown before, } \\
\text { plants used as green } \\
\text { manure }\end{array}$ & $\begin{array}{l}\mathrm{pH}>7.5 \\
\mathrm{~N}: \text { low } \\
\mathrm{P}: \text { medium } \\
\mathrm{K}: \text { medium }\end{array}$ & $\begin{array}{l}1 \text { bag/acre }+1 \text { bag } \\
\text { urea/acre }\end{array}$ \\
\hline 3 & 2 & 139 & No & & $\mathrm{pH}$ & $\begin{array}{l}1 \text { bag/acre }+1 \text { bag } \\
\text { urea/acre }\end{array}$ \\
\hline
\end{tabular}

Fertilizer use: CP 16:8:8 (34,000 MMK/1 bag - $50 \mathrm{~kg})$, Urea (27,000 MMK/1 bag - $50 \mathrm{~kg})$ - already purchased

Q: Why 16:8:8

A: Sister works for CP and recommended this for CP seed. The farmer applies extra nitrogen after 45 days in the form of urea. In plot 2 and 3, he applies less nitrogen as he believes that the soil is good

\section{Land Preparation}

Ploughed and will plough again after the rain

\section{Weeding}

Two times in the season:

- 45 days after planting just before the application of fertilizer 
- At time of fruit setting (3 months after planting)

\section{Pest Management}

Spacing, no pesticide used in the field Neighbour saw aphids and used pesticide Farmer has used seed treatment for potato (in the soil mixed with fertilizer)

For potato, farmer scouts every morning and evening

\section{Yield}

CP 808 ( 8 acres $)=1,600-1,700$ Viss/acre $=2,560-2,720 \mathrm{~kg} /$ acre $(6.3-6.7$ tonnes/ha $)$

\section{Sold}

6,000 Viss wet (Oct), 370 MMK/Viss

3,000 Viss dry (Nov), 410 MMK/Viss

\section{Soil Quality}

Has tested $\mathrm{pH}$ in the past with other companies and NGOs

$\mathrm{pH}$ is about 4.6; farmer knows that this is acidic. The company advised him to use Gypsum (lime) to adjust $\mathrm{pH}$

\section{Retailer}

Nyaung Shwe

Bayer product (Acetagro, Acetamiprid 20\% SL)

Farmer got input on Facebook from a friend who works for Bayer

\section{Notes}

- He ploughs and applies fertilizer when the rain stops and the soil is wet enough

- Farmer owns and rents out a big tractor to 50 farmers (25,000 MMK/hour). The tractor can plough about 6 acres in one day; there are 4 tractors in the village

- The government has provided funds loans to purchase tractors. The tractor was purchased in 2018 and needs to be paid in 4 years.

- Farmer uses weather forecast (general weather on the phone with 15 day forecast, weather forecasting app and listens to the radio)

- Weather is unpredictable

- Germination is about 14 days

- The farmer is part of a Facebook group

\section{Recommendations}

Double urea for field 2 and 3

Field 1 ( 4 acres): 4 bags NPK, 1 bag urea

Field 2 and 3 ( 4 acres): 4 bags NPK, 2 bags urea

Farmer 2: Ko Khan Lone (12 acres of maize)

Location: Than Te village within Than Te Village Tract

\section{Land Preparation}

Farmer rents tractor for planting and harrowing (22,000 MMK/acre)

Makes rows by hand held tractor (that he owns)

Seed: Farmer plants 6 bags per 4 acres $(7.5 \mathrm{~kg} / \mathrm{acre})$

Rows made by tractor

Row spacing: 27-78 inches

Plant spacing: 6-8 inches

In this village most farmers follow this spacing, which started because of contract farming with $\mathrm{CP}$

CP contract farming started in 2004 and stopped in 2010 because the yield became low

$\mathrm{CP}$ wanted to use sprinkler for irrigation but it was too expensive for farmers for production costs 
Farmer doesn't know how to test for germination

Table 10. Field information of farmer 2.

\begin{tabular}{|c|c|c|c|c|c|}
\hline Plot & Acres & Seed & Precursor crops & Soil & Fertilizer \\
\hline 1 & 2.5 & $\begin{array}{l}\text { AK } 111 ; \text { will plant when } \\
\text { the rain starts }\end{array}$ & Grew garlic & $\begin{array}{l}\mathrm{pH}>7.5 \\
\mathrm{~N}: \text { medium to low } \\
\mathrm{P}: \text { medium to low } \\
\mathrm{K}: \text { medium to low }\end{array}$ & $\begin{array}{l}1 \text { bag/acre }+1 \\
\text { bag urea (if } \\
\text { needed) }\end{array}$ \\
\hline 2 & 4 & $\begin{array}{l}\text { AK } 111 \text {; will plant when } \\
\text { the rain starts }\end{array}$ & $\begin{array}{l}\text { Grew lab beans; one } \\
\text { time irrigation to } \\
\text { prepare the land } \\
\text { because the soil is dry }\end{array}$ & $\begin{array}{l}\mathrm{pH}>7.5 \\
\mathrm{~N}: \text { medium to low } \\
\mathrm{P}: \text { medium to low } \\
\mathrm{K}: \text { medium to low }\end{array}$ & $\begin{array}{l}1 \text { bag/acre }+1 \\
\text { bag urea (if } \\
\text { needed) }\end{array}$ \\
\hline 3 & 5.5 & $\begin{array}{l}\text { GT } 722 ; \text { hasn't } \\
\text { purchased yet }(40,000 \\
\text { MMK+) } \\
\text { Will plan } 2 \text { acres in the } \\
\text { next few days with } \\
\text { irrigation }\end{array}$ & Grew chickpeas & $\begin{array}{l}\mathrm{pH}>7.5 \\
\mathrm{~N}: \text { very low } \\
\mathrm{P}: \text { medium } \\
\mathrm{K}: \text { medium }\end{array}$ & $\begin{array}{l}1 \mathrm{bag} / \text { acre }+1 \\
\text { bag urea (if } \\
\text { needed) }\end{array}$ \\
\hline 4 & 2 & $\begin{array}{l}\text { CP } 888 \text {; leftover seed; } \\
\text { will plant when the rain } \\
\text { starts }\end{array}$ & & $\begin{array}{l}\mathrm{pH}>7.5 \\
\mathrm{~N}: \text { low } \\
\mathrm{P}: \text { medium to low } \\
\mathrm{K}: \text { medium to low }\end{array}$ & $\begin{array}{l}1 \text { bag/acre }+1 \\
\text { bag urea (if } \\
\text { needed) }\end{array}$ \\
\hline
\end{tabular}

\section{Weeding}

Just one time around 30-45 days after planting and before fertilizing Sometimes by hand, sometimes with herbicide ( 1 bottle $=6-7,000$ MMK, need 2 bottles/acre) Labour (4 people/acre, 1 person $=4,000 \mathrm{MMK}$ )

Will most likely use herbicide

\section{Yield}

$1,300 \mathrm{Viss} /$ acre $=2,080 \mathrm{~kg} / \mathrm{acre}=5.14 \mathrm{MT} / \mathrm{ha}$

\section{Cultivars used last season}

GT 722: farmer didn't like this variety because the lifespan is longer (38,000 MMK)

GT 029 (5 acres): had lower yield than the others (200 Viss/acre lower) (32,000 MMK)

CP 888 (2 acres)

\section{Fertilizer}

All fields: Mya Ka Bar (Farmer doesn't know what ratio, 38,000/MMK)

1 bag compound/acre at planting

1 bag urea/acre $(46: 0: 0,28,000 \mathrm{MMK})$ at 45 days

\section{Pesticide}

Used a pesticide for a worm (unknown)

AWBA Cyclone 50 days after planting (2 months even without pests) $(10,000 \mathrm{MMK} / 1$ bottle $-100 \mathrm{cc})$

$5-10 \mathrm{cc} /$ acre if no pest +1 cup of urea

$20-30 \mathrm{cc} /$ acre if there is a pest +1 cup of urea

Application is based on advice from a friend

\section{Recommendations}

Not discussed with the farmer

\section{Day 2: Tuesday, 14 May 2019}

Farmer 3: Ko Aung Thu (33 acres of maize) 
Location: Hle Toe Village, Pin Pyit Village Tract, Yatsaunk Township 27 acres, 4 plots

Farmer rents the rest of his land out to another farmer ( 9 acres)

Table 11. Field information of farmer 3.

\begin{tabular}{|c|c|c|c|c|c|}
\hline Plot & Acres & Seed & Precursor crops & Soil & Fertilizer \\
\hline 1 & 7.5 & $\begin{array}{l}\text { NK } 625(42,000 \\
\text { MMK); hasn't } \\
\text { purchased yet }\end{array}$ & $\begin{array}{l}\text { Pigeon pea planted at the } \\
\text { same time; } 5 \text { corn rows, } \\
1 \text { row pigeon pea to use } \\
\text { for personal consumption } \\
\text { (no yield from pigeon } \\
\text { pea) }\end{array}$ & $\begin{array}{l}\mathrm{pH}>7.5 \\
\mathrm{~N}: \text { very low } \\
\mathrm{P}: \text { medium } \\
\mathrm{K}: \text { medium to low }\end{array}$ & $\begin{array}{l}15: 7: 8 ; 1 \text { bag/acre at } \\
\text { planting and second } \\
\text { application depends on } \\
\text { crop growth. At } \\
\text { tasselling, applies urea } \\
\text { if plant looks like it } \\
\text { needs it }\end{array}$ \\
\hline 2 & 5.5 & $\begin{array}{l}\text { CP } 808(41,000 \\
\text { MMK); wants to } \\
\text { try CP } 111 \\
(38,000 \text { MMK })\end{array}$ & Mango - 450 trees & $\begin{array}{l}\mathrm{pH}>7.5 \\
\mathrm{~N}: \text { very low } \\
\mathrm{P}: \text { between low and } \\
\text { medium } \\
\mathrm{K}: \text { medium }\end{array}$ & $15: 7: 8$ \\
\hline 3 & 2.5 & $\begin{array}{l}\text { CP } 808 \text {; wants to } \\
\text { try CP } 111\end{array}$ & & & $15: 7: 8$ \\
\hline 4 & 2.5 & $\begin{array}{l}\text { CP } 808 \text {; wants to } \\
\text { try CP } 111\end{array}$ & & & $15: 7: 8$ \\
\hline
\end{tabular}

\section{Last year's yield}

7,200 Viss for 7.5 acres $($ CP 808) $=1,536 \mathrm{~kg} / \mathrm{acre}=3.79 \mathrm{MT} / \mathrm{ha}$

15,000 Viss total for other three farms $(10.5$ acres $)=24,450 \mathrm{~kg} / 10.5$ acres $=2,328 \mathrm{~kg} / \mathrm{acre}=5.75$ MT/ha

\section{Land Preparation}

Rents a big tractor (25,000 MMK/hour) when it starts raining for harrowing/tillage Farmer plows 10 days after using hand held tractor

\section{Spacing}

Rows: exact spacing unknown, around 32 inches

He tested this, tried 90 inch rows and decided 32 inches is better

Plant spacing: 6 inches

Weeding: by machine when plant is 1.5 feet

After $1^{\text {st }}$ weeding, will use herbicide (Attack, 6,500 MMK)

\section{Seeding}

1 bag/acre

\section{Pesticide}

Did not use pesticide

At harvest he saw armyworm in 2.5 acre plot (not sure what kind of armyworm)

\section{Sold}

320 bags, stored 100 bags and 400 bags with the trader In Dec, sold at 385 MMK/Viss

\section{Seed}

Thai 222

Buys every year 
Recommendations

Not discussed with the farmer

Farmer 4: Ko Mya Lwin Oo (13 acres of maize)

Location: Inn Mee Village, Hway Village Tract, Yatsaunk Township

Table 12. Field information of farmer 4.

\begin{tabular}{|c|c|c|c|c|c|}
\hline Plot & Acres & Seed & $\begin{array}{l}\text { Before or } \\
\text { Intercropping }\end{array}$ & Soil & Fertilizer \\
\hline 1 & $\begin{array}{l}5.2 \\
(2 \text { miles } \\
\text { from home } \\
\text { and near } \\
\text { town })\end{array}$ & Thai 555 & & $\begin{array}{l}\mathrm{pH}>7.5 \\
\mathrm{~N}: \text { low } \\
\mathrm{P}: \text { medium to low } \\
\mathrm{K}: \text { low }\end{array}$ & $\begin{array}{l}\text { CP Armo 15:15:15 } \\
(30,000 \text { MMK); } 1 \\
\text { bag/acre } \\
\text { This year, planning to } \\
\text { use CP 20:10:5; } 1 \\
\text { bag/acre }\end{array}$ \\
\hline 2 & $\begin{array}{l}7.5 \text { ( } 4 \text { miles } \\
\text { from home } \\
\text { and at the } \\
\text { base of a } \\
\text { mountain) }\end{array}$ & $\begin{array}{l}\text { CP } 808 \\
(38,000 \mathrm{MMK}) \\
\text { has already } \\
\text { purchased } 7 \\
\text { bags of seed }\end{array}$ & & & $\begin{array}{l}\text { CP Armo } 15: 15: 15 \\
(30,000 \text { MMK }) ; 1 \\
\text { bag/acre } \\
\text { This year, planning to } \\
\text { use } \\
\text { CP } 20: 10: 5 ; 1 \\
\text { bag/acre }\end{array}$ \\
\hline
\end{tabular}

The farmer has 10 years of experience with corn planting

\section{Land Preparation}

Harrowed in December after cutting corn 23,000 MMK/hour for renting big tractor Waiting for rain for ploughing Will wait 15-20 days after rain to let weeds grow and then plough 1-2 days after ploughing the farmer will plant (called False Weed bed) 25-30 days after planting farmer will weed again Hand weeding, no use of herbicides

\section{Fertilizer}

Last year used CP 15:15:15 (30,000 MMK)

Planning to use 20:10:5 (30,000 MMK)

$\mathrm{CP}$ agent told the farmer if he wants to buy CP seed, has to also buy CP 20:20:5

For 5.5 acre farm, farmer doesn't know whether to grow corn or do contract farming. Is considering trying to grow Job's Tears. Shan Moe Me is aware of the FAW issue this season and wants to give farmers an alternative crop. The company is selling seed at 5,000 MMK/1 kg bag

\section{Yield}

7.5 acre plot (CP 808)

$1205 \mathrm{Viss} / \mathrm{acre}=1.9 \mathrm{MT} / \mathrm{acre}(4.8 \mathrm{MT} / \mathrm{ha})$

5.5 acre plot

3230 Viss total

$3230 / 5.5=587$ Viss/acre $=956.81$ acre $=$ almost $1 \mathrm{MT} /$ acre $(2.3 \mathrm{MT} / \mathrm{ha})$ 


\section{Day 3: Wednesday, 15 May 2019}

Farmer 5: Ma San San Yee (30+ acres of maize)

Location: Sin Thay Village, Myin Taung Village Tract in Yatsaunk Township, more than 2 hour drive without a fully paved road. 12 farmers living in the sub village - good opportunity to see if these farmers will work together this season to help each other scout/control for Fall Armyworm.

There are 200 households living in the village - all are maize farmers. They intercrop with mango, pigeon pea and avocado. We found FAW in one of the corn fields in the main village. The closest retailer is in Yatsaunk (Aung Da Gone).

Table 13. Field information of farmer 5.

\begin{tabular}{|c|c|c|c|c|c|}
\hline Farmer & Acres & Seed & Precursor crops & Soil & Fertilizer \\
\hline 1 & 14 & $\begin{array}{l}\text { NK } 625, \text { NK } \\
621, \text { CP } 808 \\
\text { and } 282\end{array}$ & & $\begin{array}{l}\mathrm{pH}>7.5 \\
\mathrm{~N}: \text { low } \\
\mathrm{P}: \text { low } \\
\mathrm{K}: \text { low }\end{array}$ & $\begin{array}{l}20: 10: 5 ; 1 \text { bag } \\
\text { compound at planting; } \\
1 \text { bag urea before } \\
\text { tasselling }\end{array}$ \\
\hline 2 & 10 & $\begin{array}{l}\text { NK } 625, \text { NK } \\
621, \text { CP } 808 \\
\text { and } 282\end{array}$ & & $\begin{array}{l}\mathrm{pH}>7.5 \\
\mathrm{~N}: \text { low } \\
\mathrm{P}: \text { low } \\
\mathrm{K}: \text { low }\end{array}$ & \\
\hline 3 & 30 & $\begin{array}{l}\text { NK } 625, \text { NK } \\
621, \text { CP } 808 \\
\text { and } 282\end{array}$ & Mango & & \\
\hline 4 & $12-13$ & $\begin{array}{l}\text { NK 625, NK } \\
621, \text { CP } 808 \\
\text { and } 282\end{array}$ & & & \\
\hline
\end{tabular}

\section{Seed}

Haven't bought seeds yet.

\section{Planting}

This does not happen on all plots at the same time, farmers help each other and need one month to finish

\section{Yield}

14 acres, 10,000 Viss $=16,300 \mathrm{~kg}=1.16 \mathrm{MT} /$ acre

10 acres $=7,000$ Viss $=11,410 \mathrm{~kg}=1.1 \mathrm{MT} /$ acre

In the field that is intercropped with mango (30 acres) $=16,000$ Viss or $869 \mathrm{~kg} / \mathrm{acre}$

$12-13$ acres $=11,000$ Viss $=17,930 \mathrm{~kg}=1.4 \mathrm{MT} /$ acre

No pests last year but at harvest, they heard about armyworm but did not see it in the area.

\section{Challenges last year}

Weather impact - 1 week after planting, not enough rain; seed couldn't germinate due to fungi At tasselling state, if there is drought the maize can't pollinate well and there is no grain filling If no rain, aphids can attack

\section{Recommendations}

1 bag compound fertilizer at planting

2 bags compound fertilizer at tasselling

Fits normal fertilizer practice and not completely required 


\section{Day 4: Thursday, 16 May 2019}

Farmer 6: Ko Khun Than Lay (5 acres of maize) - 29 years old with four children Location: Kyauk ka Char Village, Sam Hpu (Me Nei Taung) Village Tract in Ho Pone Township Joined by 2 Sathapana Loan officers

3-4 farmers grow corn in the village; there are 500 households who live in the village, many are migrant laborers in Thailand, farmers grow cheroot, paddy, avocado, turmeric, coffee

The farmer found out about Golden Paddy through Facebook. Gets knowledge from GP for different crops: coffee, corn, cheroot and uses market prices (Aung Ban market, sells at Hopong). He is able to know the average price but when he contacts the trader, price is lower.

Table 14. Field information of farmer 6.

\begin{tabular}{|c|c|l|l|l|l|}
\hline Plot & Acres & Seed & $\begin{array}{l}\text { Before or } \\
\text { Intercropping }\end{array}$ & Soil & Fertilizer \\
\hline 1 & 2 & $\begin{array}{l}\text { CP } 808 \\
\text { because of } \\
\text { neighbour }\end{array}$ & $\begin{array}{l}\text { Nothing, no manure } \\
\text { applied }\end{array}$ & $\begin{array}{l}\text { pH }>7.5 \\
\text { N: medium } \\
\text { P: inconclusive } \\
\text { K: medium }\end{array}$ & $\begin{array}{l}20: 10: 5 ; 1 \text { bag/acre at } \\
\text { planting; } 1 \text { bag/acre } \\
\text { urea }\end{array}$ \\
\hline 2 & 2 & CP 808 & $\begin{array}{l}\text { Nothing, no manure } \\
\text { applied }\end{array}$ & $\begin{array}{l}\text { Ran out of material to } \\
\text { carry out soil test? }\end{array}$ & $\begin{array}{l}20: 10: 5 ; 1 \text { bag/acre at } \\
\text { planting; } 1 \text { bag/acre } \\
\text { urea }\end{array}$ \\
\hline
\end{tabular}

\section{Planting}

The farmer will wait for rain until soil is moist enough

No germination testing, no manure, harrowing in April with a big tractor (hired)

Spacing: not precise; 2 feet between rows, 1 foot between plants

\section{Weeding}

1 time weeding 45 days after planting by spraying herbicide

\section{Scouting}

Once every two weeks

Farmer thinks he saw Fall Armyworm at harvest in November, asked neighbour farmer who told him it was FAW but did not use any control because it was already time for harvest.

\section{Yield}

Last year's yield: 5,000 Viss for all four acres $=5,000 \times 1.63=8,150 \mathrm{~kg} / 4$ acres $=2.0 \mathrm{MT} / \mathrm{acre}$

\section{Recommendations}

1 bag/acre NPK at planting, 1 bag/acre NPK at day 25, 1 bag/acre urea at day 45

Regularly scouting

\section{Day 5: Friday, 16 May 2019}

Farmer 7: Ko Naing Win Htun (5 acres of maize)

Location: Yatsaunk Village, Yatsaunk Township,

Close to main road

The farmer has 20 acres at his disposal; he plans to use 10 acres for corn. In fact, the farmer owns 50 acres of land, but he cannot afford to plant on all of the land. So, he rented out 30 acres to the neighbour, but the neighbour refuses to pay rent for land and won't give land back. 
Table 15. Field information of farmer 7.

\begin{tabular}{|c|c|l|l|l|l|}
\hline Plot & Acres & Seed & $\begin{array}{l}\text { Before or } \\
\text { Intercropping }\end{array}$ & Soil & Fertilizer \\
\hline 1 & 10 & $\begin{array}{l}288(5 \text { bags }= \\
10 \mathrm{~kg} \text { in a bag) } \\
\text { already } \\
\text { bought; CP } \\
808 \text { (5 bags) }\end{array}$ & $\begin{array}{l}\text { Manure on 4 acres } \\
\text { at planting time: } 1 \text { bag } \\
\text { fertilizer per } 1 \text { bag of seed } \\
\text { and } 1 \text { bag/acre of urea } 45 \\
\text { days after planting. } 12 \\
\text { bags of fertilizer for } 10 \\
\text { acres }\end{array}$ \\
\hline
\end{tabular}

Seed: 288 is 38,000 MMK but 32,000 MMK if bought with cash; 42,000 MMK closer to planting time. CP 808 is 38,000 . He received the Sathapana loan before he bought inputs. Farmer conducted germination test after reading Golden Paddy GAP booklet

Land Preparation: harrowing in January, used cow manure on 4 acres

Last year farmers' farm management was based on advice from a friend (from DOA): farmer didn't apply fertilizer at planting time. As a result, he had poor germination and had to destroy the crop at tasselling stage to grow other crops (pumpkin) instead. He had planted CP 808 and 288.

Farmer says he read the Golden Paddy GAP booklet and wants to follow recommendations for this year. Farmer is thinking about planting Napier grass - wants to know where he can get the seeds. CP offers input credit (seed + fertilizer, CP $808 \& 20: 10: 5,5 \%$ interest)

\section{Weeding}

The farmer wants to do weeding manually but there is labour shortage and it's expensive Plant Spacing: 6-8 inches

Row Spacing: 2.5 feet

Yield: CP 808, 800 Viss/acre $=1.3 \mathrm{MT} /$ acre

Grew 288 before and got 1200 Viss/acre before

\section{Recommendations}

1 bag/acre (20:10:5) at planting and 2 bags/acre (20:10:5) one month after planting since $20: 10: 5$ is what seems to be easily available.

If there is no labour or machine available for the weeding, the farmer can cut weeds at the surface which will kill the seeds because they can't photosynthesize

Farmer 8: Ko Kyaw Win Zaw (8 acres of maize)

Location: Ah Lel Chaung Village, Yatsaunk Township

Farmer has five plots of land spread out.

There are 150 farmers in this village. Farmer works as a trader in the village, buys and sells input. We left a poster so they can train other farmers in their village.

Table 16. Field information of farmer 8.

\begin{tabular}{|c|c|c|c|c|c|}
\hline Plot & Acres & Seed & $\begin{array}{l}\text { Before or } \\
\text { Intercropping }\end{array}$ & Soil & Fertilizer \\
\hline 1 & 5 & No plan yet & & & $\begin{array}{l}1 \text { bag ARMO (unknown } \\
\text { ratio)/acre ARMO, } 1 \\
\text { bag urea/acre } 45 \text { days } \\
\text { after planting }\end{array}$ \\
\hline
\end{tabular}




\section{Fertilizer}

1 bag ARMO (unknown ratio)/acre ARMO, 1 bag urea/acre 45 days after planting

\section{Weeding}

1 month after planting by hand

Didn't go to the field after urea application, only at harvest

\section{Yield}

NK 621, 4 acres $=6,000$ Viss, had pest infestation over 2 acres, 2 acres suffered from drought, plant growth was poor and had no yield

At harvest, they saw pest had infested the field but don't know what pest and didn't suffer yield loss

\section{Recommendations}

Same fertilizer as before: $1 \mathrm{bag} / \mathrm{acre}$ at planting, $1 \mathrm{bag}$ urea/acre at 45 days

Regularly scouting for pests and diseases is important 
Corresponding address for this report: P.O. Box 16

6700 AA Wageningen

The Netherlands

$\mathrm{T}+31(0) 317480700$

www.wur.eu/plant-research

Report WPR-959
The mission of Wageningen University \& Research is "To explore the potential of nature to improve the quality of life". Under the banner Wageningen University \& Research

Wageningen University and the specialised research institutes of the Wageningen Research Foundation have joined forces in contributing to finding solutions to important questions in the domain of healthy food and living environment. With its roughly 30 branches, 5,000 employees and 10,000 students, Wageningen University \& Research is one of the leading organisations in its domain. The unique Wageningen approach lies in its integrated approach to issues and the collaboration between different disciplines. 